\title{
Sulfonylurea Antidiabetic Agent
}

National Cancer Institute

\section{Source}

National Cancer Institute. Sulfonylurea Antidiabetic Agent. NCI Thesaurus. Code C97936.

Sulfonamide urea derivatives with antihyperglycemic activity. Sulphonylurea antidiabetic agents bind to sulfonylurea receptor type 1 (SUR1), the subunit of ATP-sensitive inwardlyrectifier potassium (IKATP) channels on the membranes of pancreatic beta cells, thereby blocking the inward current flow (influx) of positively charged $\mathrm{K}+$ ions into the cell. This results in tonic membrane depolarization, and induces a calcium ion influx through voltage-sensitive calcium channels; increased intracellular calcium ion levels trigger exocytosis of insulin-containing granules. This eventually induces secretion of insulin. The IKATP channels found in pancreatic islets are complexes of four IKATP 6.2 and four SUR1 subunits. In addition, some sulfonylureas of larger molecular size may increase the sensitivity of peripheral tissues to insulin mediated through peroxisome proliferatoractivated receptor gamma (PPARgamma). 